\title{
NEW-RECORD OF THE BUSH DOG Speothos venaticus IN A HUMAN- ALTERED LANDSCAPE IN THE WEST OF MINAS GERAIS, BRAZIL
}

\author{
NOVO REGISTRO DO CACHORRO-VINAGRE Speothos venaticus EM UMA \\ PAISAGEM ANTROPIZADA NO OESTE DE MINAS GERAIS, BRASIL
}

\author{
Fernanda Cavalcanti AZEVEDO ${ }^{1,2}$; Frederico Gemesio LEMOS $^{1,3}$; Daniel Gomes ROCHA ${ }^{4}$; \\ Alan Nilo COSTA ${ }^{1,3}$; Mozart Caetano FREITAS-JÚNIOR ${ }^{1}$ \\ 1. Programa de Conservação Mamíferos do Cerrado - PCMC, Araguari, MG, Brasil; 2. Graduate Program in Ecology, Universidade \\ Federal de Viçosa, Viçosa - UFV, MG, Brasil; 3. Universidade Federal de Goiás - UFG, Catalão, GO, Brasil; 4. Grupo de Ecologia e \\ Conservação de Felinos na Amazônia, Instituto de Desenvolvimento Sustentável Mamirauá, Tefé, AM, Brasil. \\ cavalcantifer@yahoo.com
}

\begin{abstract}
The bush dog (Speothos venaticus) is a Neotropical canid with a wide geographic distribution. Although globally listed as Near Threatened, this species was listed as Vulnerable in a recent assessment by the Brazilian government. Few records of this mammal have been reported in the Brazilian Cerrado, and it is considered extinct in several localities as a result of human landscape fragmentation. The record presented here is the first evidence of bush dog presence in the West of Minas Gerais, Brazil, which augments the species distribution with expected occurrence for this region. The study site was a transitional area between the Cerrado and Atlantic Forest biomes, in the Triângulo Mineiro region, which is a highly fragmented landscape, dominated by cattle ranches with exotic pasture species and scattered natural patches. We recorded a single bush dog individual in our survey (4,036 camera trap/night), but our sampling success was expected compared with that of other previous mammal surveys using the camera trapping method, in part, because of the species' elusive behavior and low natural densities. This record enhances knowledge of the S. venaticus distribution. Potentially, we confirm the presence of the bug dog in a region that was regarded being environmentally suitable for this species occurrence, but where it has never been reported. Moreover, our result elucidates the potential of the natural remnants to harbor threatened species in highly human-influenced and non-protected landscapes, which is the dominant scenario found in West Minas Gerais, Brasil.
\end{abstract}

KEYWORDS: Camera trapping. Conservation. Fragmentation. Neotropical savanna. Threatened species. Wild canids.

\section{INTRODUCTION}

Neotropical ecosystems harbor 11 wild canid species (WILSON; MITTERMEIER, 2009). Although globally listed as Near Threatened by the International Union for Conservancy of Nature and Natural Resources (IUCN, 2015), four of these canids, including the bush dog (Speothos venaticus, Lund, 1942), were listed as Threatened (i.e., Category Vulnerable) in a recent assessment by the Brazilian government (MMA, 2014). In the Cerrado biome, which is considered a biodiversity hot spot (MYERS et al., 2000), the bush dog is classified as Endangered (JORGE et al., 2013) with their populations decreasing due to ongoing habitat loss and fragmentation associated to the growing risk of attacks and diseases transmitted by domestic dogs(DEMATTEO; LOISELLE, 2008; DEMATTEO; MICHALSKI; LEITE-PITMAN, 2011; OLIVEIRA, 2009).

Different from other nocturnal and less sociable canids species of South American, the bush dog is a small canid (4-8 kg) with diurnal habits and that has a quite peculiar strong social behavior of living in packs of up to 12 individuals (BEISIEGEL; ADES, 2002; LIMA et al., 2012). However, even though they are active during the day and live in relatively large groups, the species is rarely recorded in surveys because of its elusive behavior (LIMA; JORGE; DALPONTE, 2009; LIMA et al., 2015; MICHALSKI, 2010; ZUERCHER; VILLALBA, 2002) and low natural densities (DEMATTEO; MICHALSKI; LEITE-PITMAN, 2011). Therefore, the current distribution and ecology of the species is still poorly understood, although lately there have been some substantial advances in knowledge regarding the bush dog (BEISIEGEL; ADES, 2002; DEMATTEO et al., 2006; LIMA; JORGE; DALPONTE, 2009; LIMA et al., 2015; OLIVEIRA, 2009).

The bush dog geographic distribution ranges from Panama to northern Argentina, including almost the entire Brazilian territory (BEISIEGEL; ZUERCHER, 2005). Along this distribution, the species has been observed in many different vegetation types, such as forests, wet savannas, open habitats, and even semi-arid environments (BEISIEGEL; ZUERCHER, 2005; BEISIEGEL, 
2009; FERNANDES-FERREIRA et al., 2011; JORGE et al., 2013; SILVEIRA et al., 1998; TERIBELE et al., 2012). However, this wild canid seems to be sensitive to habitat degradation, preferring native vegetation areas over altered ones (LIMA et al., 2015). Unsurprisingly, only $20 \%$ of bush dog historical records are from altered or fragmented habitats (DEMATTEO; LOISELLE, 2008), and the most recent occurrence outside protected areas was in Northwest Minas Gerais (FERREIRA et al., 2015). Due to the bush dog is naturally rare and occurs at low population densities, very few occurrences were reported in the Brazilian Cerrado, which is the center of its potential geographic distribution (ICMBIO, 2015; JORGE et al., 2013; OLIVEIRA, 2009). Therefore, most of where this canid species occurs still remains unknown, which increases the need for studies to determine the current bush dog distribution and importance of publishing new records. We herein present a new bush dog record in a region where the species is expected, but has never been confirmed.

\section{CONTENTS}

As part of a long-term monitoring project on wild ecology of large felids (i.e., Puma concolor and Leopardus pardalis), performed from 2009 to present, we have constantly surveyed medium- and large-sized terrestrial mammals with camera traps in the Araguari River basin located at the Triângulo Mineiro region in West Minas Gerais $\left(18^{\circ} 466^{\prime} \mathrm{S} / 48^{\circ} 14^{\prime} \mathrm{W}\right.$ and $18^{\circ} 21^{\prime} \mathrm{S} / 48^{\circ} 38^{\prime} \mathrm{W}$; Fig. 1). The study site was a transitional area between the Cerrado and Atlantic forest, which follow the basin of two large rivers, Araguari and Paranaiba (Figure 1; LOPES et al., 2012). The area has a highly fragmented landscape dominated by cattle ranches with exotic pasture (up $75-80 \%$ of area) and scattered natural patches of savanna and mesophytic seasonal forest (sensu OLIVEIRA-FILHO; RATTER, 2002). From July 2014 to March 2015, we conducted a camera trap survey along a nonlinear transect with 34 camera trap stations spaced, on average, $1.9 \mathrm{~km}$ from each other (range:0.3$8.0 \mathrm{~km}$; Fig. 1). The survey covered an area of up to $300 \mathrm{~km}^{2}$, with a total sampling effort of 4,036 camera trap/night. Camera trap stations were established on trails used by animals and abandoned dirt roads within natural fragments. Each station was composed of two camera traps (Bushnell $^{\odot}$ Nature view HD Essential, Kansas, USA), that faced each other and spaced 5-8 $\mathrm{m}$ apart. No bait was used.

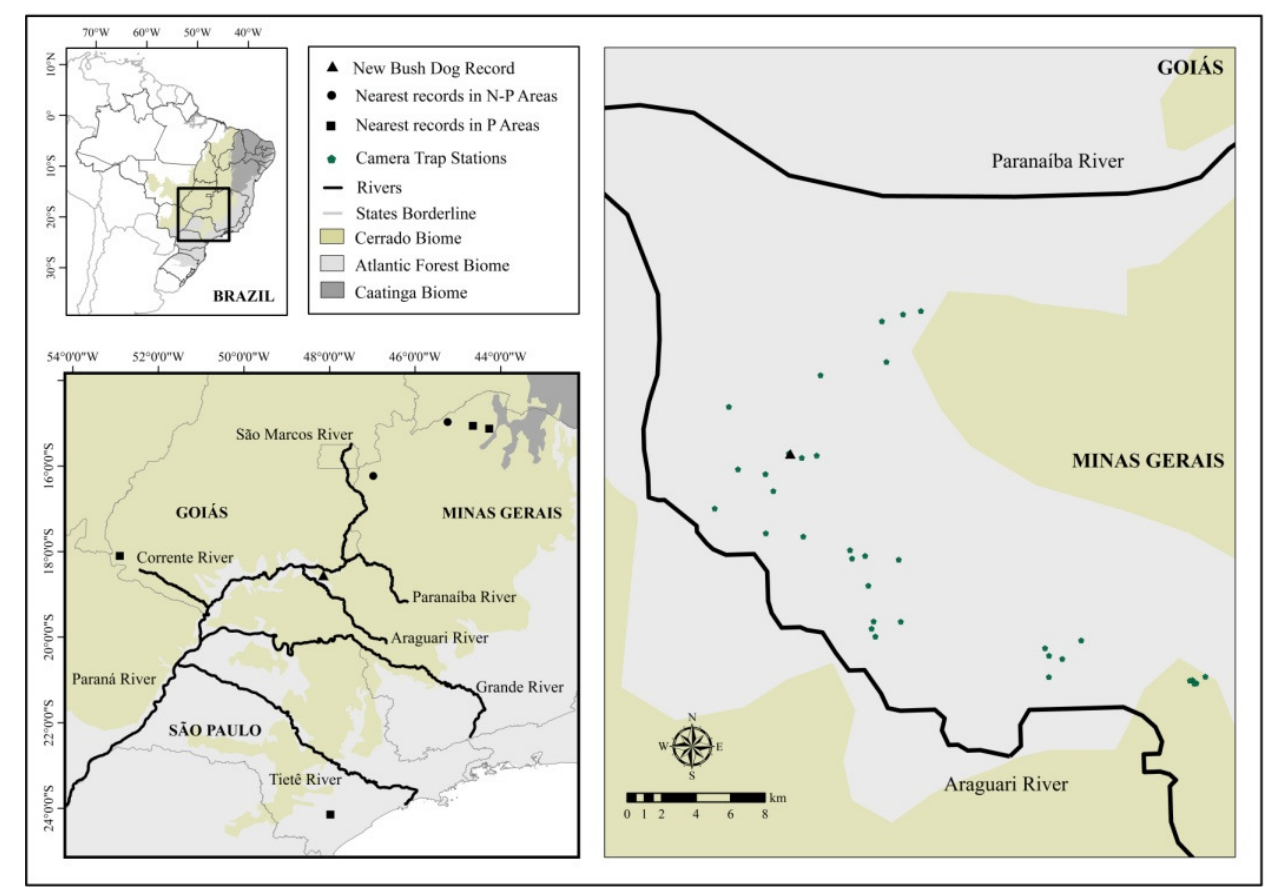

Figure 1. Maps with the new bush dog (Speothos venaticus) record in the Triângulo Mineiro region, West Minas Gerais. Down left, the new record and nearest current records in non-protected areas (N-P) and potential populations recorded in protected areas $(\mathrm{P})$ at states of Minas Gerais (FERREIRA et al., 2015), Goiás (SILVEIRA et al., 1998), and São Paulo (BEISIEGEL, 2009), Brazil. Right, the study site with camera trap stations and the location of new record between Araguari and Paranaiba rivers. 
The bush dog record consists of footage of a single adult individual that was recorded on 20 September 2014 at 22:54h (18 29'59.72”S/48 31'53.01”'W; elevation: $692 \mathrm{~m})$. The animal ran past the front of a camera trap (Fig. 2) installed on an abandoned dirt road inside a large riparian forest fragment $(1,400 \mathrm{ha})$. The camera that captured the bush dog image was part of the first continuous mammal survey carried in the region. Despite scattered reports from the local community during occasional interviews over the seven years that we have worked in the region, the camera trap record was the first confirmed evidence of local bush dog occurrence. The low detection rate in our survey, in part, could be consequence of the species' tendency to avoid walking along roads and tracks (LIMA; JORGE; DALPONTE, 2009), or actively avoiding trails of large predators (DEMATTEO et al., 2009). Indeed, the sites chosen for camera trap stations were selected because of their great potential to record pumas (i.e., our focal species). However, our bush dog record rate was close to what was expected relative to sampling success reached by many other previous mammal surveys using the camera trap method (on average, 1 record per 3,140 camera trap/night; BEISIEGEL, 2009; FERREIRA et al., 2015; FUSCO-COSTA; INGBERMAN, 2012; MICHALSKI, 2010; MICHALSKI; OLIVEIRA; MICHALSKI，2015; ROCHA et al., 2015). Such difficulties in recording $S$. venaticus have been more frequently attributed to the species' elusive behavior and low natural densities (DEMATTEO; MICHALSKI; LEITEPITMAN, 2011; LIMA; JORGE; DALPONTE, 2009; LIMA et al., 2015; MICHALSKI, 2010; ZUERCHER; VILLALBA, 2002).

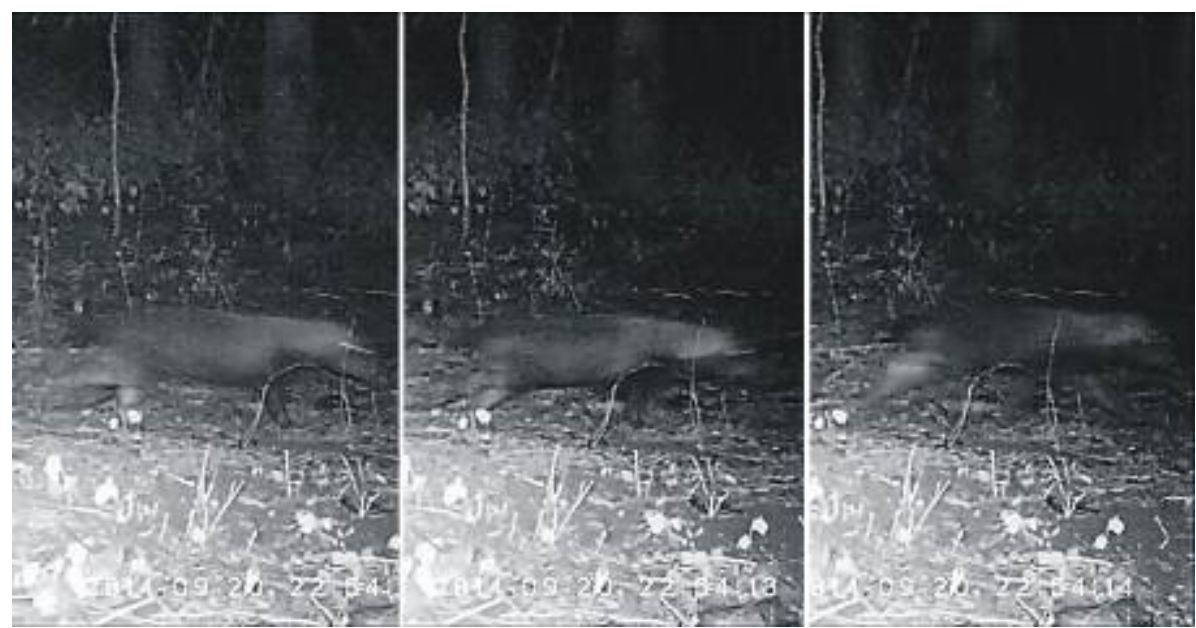

Figure 2. Footage frames of the bush dog (Speothos venaticus) recorded in September 2014 at the Araguari River basin, Triângulo Mineiro region, West Minas Gerais, Brazil.

Our bush dog record in the Triângulo Mineiro region, West Minas Gerais, bridges a gap in the known species occurrence within its expected geographical distribution in the Brazilian territory (JORGE et al., 2013). Despite that current highly fragmented landscape, Triângulo Mineiro region was regarded being environmentally suitable for the bush dog occurrence(ICMBIO, 2015). In addition, recent studies indicated that bush dogs have large home ranges $\left(140-650 \mathrm{~km}^{2}\right.$ per animal group) and can live in altered landscape - if that connectivity between the natural patches remains (BEISIEGEL, 2009; LIMA et al., 2012, 2015; MICHALSKI, 2010). The nearest recent record of this wild canid in a non-protected area in Minas Gerais was from Unaí Municipality (approx. 290km; Fig. 1; FERREIRA et al., 2015; to historical records in Minas Gerais and Goiás see DEMATTEO;
LOISELLE, 2008; FERNANDES-FERREIRA et al., 2011; FONSECA; REDFORD, 1984). Nearest currently known populations of bush dogs in protected areas are in the West of Goiás State at Emas National Park (approx. 450km; Fig. 1; SILVEIRA et al., 1998), the North of Minas Gerais State at Grande Sertão Veredas-Peruaçu Protected Areas Complex (approx. 500km; Fig. 1; FERREIRA et al., 2015) and the South of São Paulo State at Carlos Botelho State Park (approx. 640km; Fig. 1; BEISIEGEL, 2009). Beyond $650 \mathrm{~km}$, potential populations have been occurred in Cerrado areas of the states of Mato Grosso and Mato Grosso do Sul (LIMA; JORGE; DALPONTE, 2009; LIMA et al., 2012; TERIBELE et al., 2012). The long distances between areas with confirmed populations of bush dogs and our study region includes extensively modified landscapes (i.e., crop fields, pastures, 
paved roads with intense traffic, hydroelectric dams and many cities). Therefore, such landscapes strongly indicated a low probability of the recorded animal is only a transient individual coming from distant populations and not a potential resident animal.

There is a need to acquire further knowledge regarding of bush dogs in nature, including intensifying research efforts in non-protected areas, since this is the dominant scenario in great part of the species distribution (CARVALHO; MARCOJÚNIOR; FERREIRA, 2009; KLINK; MACHADO, 2005). Given the scarcity of basic information about bush dogs, records like the one presented here highlight the potential of native Cerrado fragments in human-modified landscapes to harbor rare and threatened species. The structural connectivity of the landscapes is another essential aspect that needs to be considered for conserving species that requires large home ranges, such as the bush dog (LIMA et al., 2015). The studied region represents a unique ecotone of biomes that belong to two important hotspots - the Cerrado and Atlantic Forest (MYERS et al., 2000), which favors high regional diversity (i.e., due the turnover). Moreover, along the valleys of Araguari River and Paranaiba River still exist numerous - and relatively close - protected private natural fragments (as predicted by Brazilian Environmental Act). Probably by this reason, wildlife in the surveyed area includes other South American threatened species (e.g., hoary fox Lycalopex vetulus, maned wolf Chrysocyon brachyurus, and giant armadillo Priodontes maximus; LEMOS, F.G.; AZEVEDO, F.C. unpublished). Therefore, our information supports the importance of the maintaining natural vegetation outside government-protected areas due to their role in species persistence and conservation.

\section{ACKNOWLEDGEMENTS}

We are in debit with landowners for their hospitality and cooperation with Programa de Conservação Mamíferos do Cerrado projects. We thank anonymous reviewers and editors that provided very helpful comments on the manuscript. Funding was provided by Capim Branco Energy Company - CCBE. F.C. Azevedo was supported by a doctoral fellowship from the HIDROEX (UNESCO/BID).

RESUMO: O cachorro-vinagre (Speothos venaticus) é um canídeo Neotropical com uma ampla distribuição geográfica. Embora seja listada globalmente como Quase Ameaçada, esta espécie foi classificada como Vulnerável em recente avaliação do governo brasileiro. Poucos registros para este mamífero foram reportados no Cerrado brasileiro, sendo considerado extinto em várias localidades como resultado da fragmentação da paisagem provocada pelo homem. $\mathrm{O}$ registro apresentado aqui é a primeira evidência de ocorrência do cachorro-vinagre no oeste de Minas Gerais, Brasil, o que confirma a distribuição da espécie com ocorrência esperada para esta região. O local de estudo é uma área transicional entre os biomas Cerrado e Mata Atlântica, na região do Triângulo Mineiro, sendo uma paisagem altamente fragmentada dominada por fazendas de criação de gado com pastagem exótica e fragmentos naturais dispersos. Nós registramos somente um único cachorro-vinagre na nossa amostragem (4.036 armadilhas fotográficas/noite), mas o nosso sucesso de amostragem foi esperado comparado com os resultados de outros levantamentos de mamíferos utilizando o método de armadilhamento fotográfico, em parte, devido ao comportamento alusivo e a baixa densidade natural da espécie. Este registro aumenta o conhecimento da distribuição de $S$. venaticus. Potencialmente, nós confirmamos a presença do cachorro-vinagre em uma região que foi considerada com adequabilidade ambiental para a ocorrência da espécie, mas onde ela não havia sido reportada até momento. Além disso, nosso resultado também reforça o potencial dos remanescentes naturais em abrigar espécies ameaçadas da fauna em paisagens altamente afetadas pelo homem e não protegidas, a qual representa o cenário dominante encontrado no oeste de Minas Gerais, Brasil.

PALAVRAS-CHAVE: Armadilhamento fotográfico. Conservação. Fragmentação. Savana Neotropical. Espécies ameaçadas. Canídeos silvestres.

\section{REFERENCES}

BEISIEGEL, B. M. First camera trap record of bush dogs in the state of São Paulo, Brazil. Canid News, v. 12, n. 5, p. 1-5, 2009. Available in: http://www.canids.org/canidnews/12/Bush_dogs_in_Sao_Paulo.pdf. Accessed: 28 Apr. 2016. 
BEISIEGEL, B. M.; ADES, C. The Behavior of the bush dog in the (Speothos venaticus Lund, 1842) field: a review. Revista de Etologia, v. 4, n. 1, p. 17-23, 2002. Available in:

http://www.etologiabrasil.org.br/sbet/revista/Vol_4_1_017.pdf. Accessed: 28 Apr. 2016.

BEISIEGEL, B. M.; ZUERCHER, G. L. Speothos venaticus. Mammalian Species, v. 783, p. 1-6, Dec. 2005. http://dx.doi.org/10.1644/783.1

CARVALHO, F. M. V.; MARCO-JÚNIOR, P.; FERREIRA, L. G. The Cerrado into-pieces: Habitat fragmentation as a function of landscape use in the savannas of central Brazil. Biological Conservation, $v$. 142, n. 7, p. 1329-1403, Jul. 2009. http://dx.doi.org/10.1016/j.biocon.2009.01.031

DEMATTEO, K. E.; PORTON, I. J.; KLEIMAN, D. G.; ASA, C. S. The effect of the male bush dog (Speothos venaticus) on the female reproductive cycle. Journal of Mammalogy, v. 87, n. 4, p. 723-732, Aug. 2006. http://dx.doi.org/10.1644/05-MAMM-A-342R1.1

DEMATTEO, K. E.; RINAS, M. A.; SEDE, M. M.; DAVENPORT, B.; ARGÜELLES, C. F.; LOVETT, K.; PARKER, P. G. Detection Dogs: an effective technique for bush dog surveys. Journal of Wildlife Management, v. 73, n. 8, p. 1436-1440, Nov. 2009. http://dx.doi.org/10.2193/2008-545

DEMATTEO, K. E.; LOISELLE, B. A. New data on the status and distribution of the bush dog (Speothos venaticus): evaluating its quality of protection and directing research efforts. Biological Conservation, v. 141, n. 10, p. 2494-2505, Oct. 2008.http://dx.doi.org/10.1016/j.biocon.2008.07.010

DEMATTEO, K.; MICHALSKI, F.; LEITE-PITMAN, M. R. P. Speothos venaticus. The IUCN Red List of Threatened Species, 2011.http://dx.doi.org/10.2305/IUCN.UK.2011-

2.RLTS.T20468A9203243.en

FERNANDES-FERREIRA, H.; FEIJÓ, J. A.; GURGEL-FILHO, N. M.; MENDONÇA, S. V.; ALVES, R. R. N.; LANGGUTH, A. An unexpected record of Speothos venaticus (Carnivora, Canidae) in the Caatinga domain. Revista Nordestina de Biologia, v. 20, n. 2, p. 59-65, Dec. 2011. Available in:

http://periodicos.ufpb.br/ojs/index.php/revnebio/article/view/11910/6975. Accessed: 28 Apr. 2016.

FERREIRA, G. B.; OLIVEIRA, M. J. R.; PAULA, R. C.; RODRIGUES, F. H. G.; CARMO, E. D. C. Regionally extinct species rediscovered: the bush dog Speothos venaticus in Minas Gerais, south-eastern Brazil. Oryx, v. 49, n. 1, p. 60-63, Jan. 2015. http://dx.doi.org/10.1017/S0030605314000118

FONSECA, G. A. B.; REDFORD, K. H. The mammals of IGBE's ecological reserve, Brasilia and an analysis of the role of gallery forests in increasing diversity. Revista Brasileira de Biologia, v. 44, p. 517-523, 1984.

FUSCO-COSTA, R.; INGBERMAN, B. Records of the bush dog Speothos venaticus in a continuous remnant of coastal Atlantic Forest in southern Brazil. Oryx, v. 47, n. 1, p. 105-108, Jan. 2013.

http://dx.doi.org/10.1017/S003060531200052X

ICMBIO. Sumário Executivo do Plano de Ação Nacional para a Conservação do Cachorro-vinagre. Brasília: MMA/ICMBio, 2015. 8 p. Available in: http://www.icmbio.gov.br/portal/biodiversidade/faunabrasileira/plano-de-acao/2834-planode-acao-nacional-para-a-conservacao-do-cachorro-vinagre.html. Accessed: 28 Apr. 2016

IUCN. The IUCN Red List of Threatened Species v. 2015.4. Available in: http://www.iucnredlist.org. Accessed: 3 Nov. 2015. 
JORGE, R. S. P.; BEISIEGEL, B. M.; LIMA, E. S.; JORGE, M. L. S. P.; LEITE-PITMAN, M. R. P.; PAULA, R. C. Avaliação do estado de conservação do Cachorro-vinagre Speothos venaticus (Lund, 1842) no Brasil.

Biodiversidade Brasileira, v. 3, n. 1, p. 179-190, 2013. Available in:

http://www.icmbio.gov.br/portal/images/stories/biodiversidade/fauna-brasileira/avaliacao-dorisco/carnivoros/cachorro-vinagre_speothos_venaticus.pdf. Accessed: 28 Apr. 2016.

KLINK, C. A.; MACHADO, R. B. Conservation of the Brazilian Cerrado. Conservation Biology, v. 19, n. 3, p. 707-713, jun. 2005.http://dx.doi.org/10.1111/j.1523-1739.2005.00702.x

LIMA, E. S.; DEMATTEO, K. E.; JORGE, R. S. P.; JORGE, M. L. S. P.; DALPONTE, J. C.; LIMA, H. S.; KLORFINE, S. A. First telemetry study of bush dogs: home range, activity and habitat selection. Wildlife Research, v. 39, n. 6, p. 512-519, Aug. 2012. http://dx.doi.org/10.1071/ WR11176

LIMA, E. S.; JORGE, M. L. S. P.; JORGE, R. S. P.; MORATO, R. G. The bush dog Speothos venaticus: area requirement and habitat use in cultivated lands. Oryx, v. 49, n. 01, p. 64-70, Sep. 2015.

http://dx.doi.org/10.1017/S0030605314000076

LIMA, E. S.; JORGE, R. S. P.; DALPONTE, J. C. Habitat use and diet of bush dogs, Speothos venaticus, in the Northern Pantanal, Mato Grosso, Brazil. Mammalia, v. 73, n. 1, p. 13-19, Jan. 2009.

http://dx.doi.org/10.1515/MAMM.2009.002

LOPES, S. F.; SCHIAVINI, I.; OLIVEIRA, A. P.; VALE, V. S. An Ecological Comparison of Floristic Composition in Seasonal Semideciduous Forest in Southeast Brazil: Implications for Conservation.

International Journal of Forestry Research, v. 2012, p. 1-14, 2012.http://dx.doi.org/10.1155/2012/537269

MICHALSKI, F. The bush dog Speothos venaticus and short-eared dog Atelocynus microtis in a fragmented landscape in southern Amazonia. Oryx, v. 44, n. 02, p. 300-303, Apr. 2010.

http://dx.doi.org/10.1017/S0030605309990871

MICHALSKI, L. J.; OLIVEIRA, T. G. DE; MICHALSKI, F. New record for bush dog in Amapá State , Eastern Brazilian Amazonia. Canid Biology \& Conservation, v. 18, n. 2, p. 3-5, 2015. Available in: http://www.canids.org/CBC/18/bush_dogs_eastern_Brazilian_Amazonia.pdf. Accessed: 28 Apr. 2016.

MMA. Portaria n. 444/2014 Fauna Ameaçada, 2014. Available in:

http://www.icmbio.gov.br/portal/biodiversidade/fauna-brasileira/lista-de-especies. Accessed: 3 Nov. 2015.

MYERS, N.; MITTERMEIER, R. A.; MITTERMEIER, C.G.; FONSECA, G.A. B.; KENT, J. Biodiversity hotspots for conservation priorities. Nature, v. 403, n. 6772, p. 853-858, Feb. 2000.

http://dx.doi.org/10.1038/35002501

OLIVEIRA, T. G. Distribution, habitat utilization and conservation of the Vulnerable bush dog Speothos venaticus in northern Brazil. Oryx, v. 43, n. 02, p. 247-253, Apr. 2009.

http://dx.doi.org/10.1017/S0030605307002347

OLIVEIRA-FILHO, A. T.; RATTER, J. T. Vegetation physiognomies and woody flora of the Cerrado biome. In: OLIVEIRA, P. S.; MARQUIS, R. J. (Ed.). The Cerrados of Brazil: ecology and natural history of a Neotropical savanna. New York: Columbia University Press, 2002. p. 91-120.

ROCHA, D. G.; RAMALHO, E. E.; ALVARENGA, G. C.; GRÄBIN, D. M.; MAGNUSSON, W. E. Records of the bush dog (Speothos venaticus) in Central Amazonia, Brazil. Journal of Mammalogy, v. online, p. 1-4, Sep. 2015. http://dx.doi.org/10.1093/jmammal/gyv145

SILVEIRA, L.; JÁCOMO, A. T. A.; RODRIGUES, F. H. G.; DINIZ-FILHO, J. A. F. Bush dogs (Speothos venaticus) in Emas National Park, Central Brasil. Mammalia, v. 62, n. 3, p. 446-449, Jan. 1998. 
TERIBELE, R.; CONCONE, H. V. B.; GODOI, M. N.; BIANCHI, R. C.; SANTOS, J. C. C.; MAURO, R. A.; XAVIER-FILHO, N.L.; MELLO, A. V. New records for bush dog in Mato Grosso do Sul, Brazil. Canid News, v. 15, p. 1-4, 2012. Available in: http://www.canids.org/canidnews/15/Bush_dog_MatoGrosso.pdf. Accessed: 28 Apr. 2016.

WILSON, D. E.; MITTERMEIER, R. A. Handbook of the mammals of the world, vol. 1, Carnivores. Barcelona: Lynx Editions, 2009. 727 p.

ZUERCHER, G. L.; VILLALBA, R. D. Records of Speothos venaticus Lund, 1842 (Carnivora, Canidae) in eastern Paraguay. Mammalian Biology, v. 67, n. 3, p. 185-187, May. 2002. http://dx.doi.org/10.1078/16165047-00027 